\title{
EquiLIBRIUM
}

Quarterly Journal of Economics and Economic Policy

2015 VOLUME 10 ISSUE 2, June

p-ISSN 1689-765X, e-ISSN 2353-3293

www.economic-policy.pl

Kamela-Sowińska, A. (2015). Accounting Integration Issues of EU Member States. Equilibrium. Quarterly Journal of Economics and Economic Policy, 10(2), pp. 223-236, DOI: http://dx.doi.org/10.12775/ EQUIL.2015.021

\author{
Aldona Kamela-Sowińska* \\ Poznan University of Economics, Poland
}

\section{Accounting Integration Issues of EU Member States}

\section{JEL Classification: $M ; K 2$}

Keywords: legal norm; accounting; integration, European Union

\begin{abstract}
The aim of this article is to discuss the dilemmas over the integration of accounting in EU member states. The dilemma could be divided into the following main groups. Dilemma of the user of financial statements. This dilemma consists in determining for whom the integration of accounting in EU is crucial, and who is the intended beneficiary of integration. Dilemma arising from the lack of theoretical framework for drafting directives and standards: the accounting paradigm assuming that accounting is strictly quantitative. Accounting is a social science, whereas the accounting practice has greater influence on social, rather than purely economic, reality. Dilemma over legal regulations and the legitimization of standard setters could be attributed to accounting regulations as legal norms. A classic example of this might be the transition from rule-based to principle-based IFRSs.

The dilemma over the legitimization of standard setters has its roots in the legal aspect of accountancy. In order to solve it, it is necessary to answer the question: 'who controls the processes of accounting integration?' since the participants of this process often present divergent viewpoints, and sometimes even opposite priorities. Dilemma over the politicization of accountancy. The more globalized and complex the economic environment is, the more of political intervention there is
\end{abstract}

(C) Copyright Institute of Economic Research \& Polish Economic Society Branch in Toruń Date of submission: December 15, 2014; date of acceptance: May 19, 2015

* Contact: aldona.kamela-sowinska@ue.poznan.pl, Faculty of Accountancy, Poznan University of Economics, aleja Niepodległości 10, Poznań, Poland 
expected to be in the standard setting process, affected by global geopolitical trends.

\section{Introduction}

Despite the economic turmoil, economic crises, the conflict in Ukraine and other European turbulences, the EU integration as we know it depicted by the EU politicians seems an idealized reality created by smart diplomatic rhetoric. This pertains also to accounting, or the dilemmas over the its integration in the EU to be more precise. The integration dilemmas could be divided into the following main groups:

- dilemma of the user of financial statements,

- dilemma arising from the lack of theoretical framework for drafting directives and standards,

- dilemma over legal regulations and the legitimization of standard setters,

- dilemma over the politicization of accountancy.

\section{Methodology}

The paper uses theories of globalization focusing on the "race-to-thebottom" (Berle \& Means, 1932). Some describe the concept as the "race to efficiency," drawing attention to the way in which global business is using financial reports and economic and political power to shift accountancy toward a more geopolitical practice. As to accountancy, basic theories are used, in particular principle-based accounting theory and normative theory of accounting.

\section{Practical implications}

The paper shows that EU corporations, accounting firms and politicians together with Europeans professional bodies are the real force able to transform accountancy in a more integrated way, relevant to EU countries. 


\section{Dilemma of the Users of Financial Statements}

There are a number of ways in which the evaluation of accountancy can help policy makers better understand the world they are bound to manage. This dilemma consists in determining for whom the integration of accounting in the EU is crucial, and who the intended beneficiary of integration is. Modern standard setters, especially those setting IFRSs, claim universal value of the solutions they develop, as well as moral neutrality, yet in fact this logically contradicts the claim that investors are the main users of financial statements. Widespread international adoption of IFRS offers equity investors a variety of potential advantages. These include (International Financial Reporting Standards (IFRS): pros and cons for investors, (Ball, 2006):

- IFRS promise more accurate, comprehensive and timely financial statement information, relative to the national standards they replace for public financial reporting in most of the countries adopting them, Continental Europe included. To the extent that financial statement information is not known from other sources, this should lead to a moreinformed valuation in equity markets, and hence ensure lower risk to investors.

- By eliminating many international differences in accounting standards and standardizing reporting formats, IFRS eliminate many of the adjustments analysts historically have made in order to make the financials of companies more internationally comparable. IFRS adoption could, therefore, reduce the cost of processing financial information to investors. The gain would be greatest for institutions that create large, standardized financial databases.

- One benefit is that reducing the cost of processing financial information most likely increases the efficiency with which the stock market translates it into prices. Most investors may be expected to benefit from an improved market efficiency.

- Reducing international differences in accounting standards to some degree facilitates removing barriers to cross-border acquisitions and divestitures, which in theory will reward investors with higher takeover premiums;

In general, IFRS offer increased comparability and hence reduced information costs and information risk to investors.

Literature is full of professional judgments on IFRS. They offer several additional, yet indirect, advantages to investors. Since higher information quality should reduce both the risk to all investors resulting from share ownership and the risk to less-informed investors caused by adverse selec- 
tion, in theory it should lead to a reduction in the cost of equity capital. This would increase share prices, and would make new investments by firms more attractive, other things equal. Indirect advantages to investors arise from improving the usefulness of financial statement information in contracting between firms and a variety of parties, notably lenders and managers (Watts \& Zimmerman, 1986)

Small investors are less likely than investment professionals to be able to anticipate financial statement information from other sources. Having regard to the treaty on the functioning of the European Union; having regard to the proposal from the European Commission, after transmission of the draft legislative act to the national parliaments; having regard to the opinion of the European Economic and Social Committee acting in accordance with the ordinary legislative procedure the European Parliament and of the council of 26 June 2013 introduced the Directive 2013/34/UE of on the annual financial statements, consolidated financial statements and related reports of certain types of undertakings.

This Directive should ensure that the requirements for small undertakings are to a large extent harmonized throughout the European Union. This Directive is based on the "think small first" principle. In order to avoid placing disproportionate administrative burdens on those undertakings, Member States should only be allowed to require a few disclosures by way of notes in addition to mandatory notes. In case of a single filing system, however, Member States may in certain cases require a limited number of additional disclosures where these are explicitly required by their national tax legislation and are strictly necessary for the purposes of tax collection. It should be possible for Member States to impose requirements on medium-sized and large undertakings that go beyond the minimum requirements prescribed by this Directive (directive 2013/34/EU of the European Parliament and of the Council of 26 June 2013 EC).

Many factors are linked to the financial crisis, and it is likely that poor implementation and application of fair value accounting rules has also had some effect. For example, default risk assessment was compromised, and the amount of subprime mortgage originations grew from approximately $8 \%$ of total residential mortgage originations in 2001-2003 to over $20 \%$ in each year from 2004 through early 2007 (Ryan, 2008, pp. 1605-1638).

Standards should be reconsidered, with less emphasis being placed on accounting rules that anticipate future income and overstate income and assets, and focusing more on appropriate implementation and standards that require bad news to be recognized when it becomes known. This timely recognition of losses would provide greater transparency to investors about the actual performance of their investments. While standards should allow 
for innovation and growth, accounting for company's performance must provide an accurate representation of its historical financial performance and health, with comments on fair value included only in notes or other sections of the financial statements. Other suggestions for revisions to the standards include forcing banks to increase the actual capital requirements in good economic times to build equity reserves to be used in the event of a subsequent downturn, and separating credit losses from other changes in fair value in the financial statements. Such objectives can be fulfilled through appropriate standards accompanied by greater enforcement, sound auditing practices, and adequate regulatory vigilance. Consideration should be given to these matters, particularly as standards will likely continue to evolve in light of future convergence with IFRS (Kothari \& Lester, 2011, Kothari 2012).

The role financial reporting for fair values, asset securitizations, and derivatives played in the financial crisis is being scrutinized. The discussion is focused on banks as the centere of the financial crisis. In response to the situation, the FASB and IASB have taken steps to improve disclosures relating to asset securitizations. The approach to accounting for securitizations in the IASB's Exposure Draft requiring banks to recognize whatever assets and liabilities they have after securitization is completed, better reflects the economics underlying the securitization transaction, derivatives, disclosure of more disaggregated information, disclosure of the sensitivity of derivatives' fair values to changes in market risk variables, and the implementation of a risk-equivalence approach to enable investors to better understand the leverage inherent in derivatives. Although accounting standard setters and bank regulators should find a common ground, they keep ignoring other users of financial statements and their role to reassure the society about the stability of the financial system.

In fact, today's users of financial statements are not only investors and banks. In the globalised world, with online transaction systems, economic analytical centres, virtual money, and data analysis software, which investors make their economic decisions based on audited balance sheets submitted to them six months after the reporting date? If investors bought and sold shares according to financial result, perhaps we wouldn't witness financial crises. The usefulness of financial information has been broadly questioned, due to its late presentation and complexity. The problem is that it's not useless, but rather inappropriate. The process of drafting the international standards is sometimes described as 'patch approach,' 'piece-made approach,' or 'mix attribute model' (see ISAR discussion 2010, Geneva). Hence, maybe the IFRS Interpretation Committee should add 'self-serving body' to complement their name. Now it is lawyers, prosecutors, judges, or 
inspectors from the Supreme Chamber of Control, the Central Anticorruption Bureau, or the Central Bureau of Investigation who make decisions affecting the lives of others, based on financial statements. The target group of financial statements has changed dramatically in recent years.

"Perhaps some members of the profession would prefer to stay out of limelight. But this would risk having no voice in the development of policy. It would also open the profession to accusations that it was not playing a full role in civil society. Lawyers doctors, and other leading professions have long developed a public policy role. If accountancy accepted the wider role, there would be significant potential advantages for accountants and, indeed, for the quality of debate (Travers, 2014).

Thus, to be overarching, the definition of the user of financial statements should read: "the user of financial statements is every person that takes binding decisions based on financial statements". Such a definition makes the target group more universal, i.e. features the investor.( KamelaSowinska, 2011)

\section{Dilemma Arising from the Lack of Theoretical Framework for Drafting Directives and Standards}

The globalization of the world of commerce has revealed the urge for international harmonization and standard setting in accounting and audit.

"If a conceptual framework is an attempt to operationalize the accounting theory, the first stumbling block is the lack of agreement on the nature and scope of this theory. So rather than having a common starting point and then a disagreement about in which direction one should go, there appear to be many different starting points, each with its own set of future avenues" (Higson, 2003, p. 84).

The accounting paradigm assuming that accounting is strictly quantitative, i.e. in its nature based on numbers (e.g. financial result) which are then used to make economic decisions, is becoming less ubiquitous. Accounting is a social science, whereas the accounting practice has greater influence on social, rather than purely economic, reality. Thus, IFRSs should be named 'IFRSs for financial markets' to make a clear division between financial economy and 'real' economy. In principle, psychologists or experts in social and cultural studies are not engaged in setting directives, especially 
specific standards. This could be reflected in the composition of IASB's bodies and other European institutions dealing with the integration of accounting, with top-notch experienced auditors, accountants, financial directors serving as former directors or heads of audit firms, banks, or rating agencies.

IFRS Foundation does not have a research body. Its Commissions and Working Groups are composed of distinguished figures, but they are only practitioners and none of them is a lawyer, psychologist or a specialist in cultural or social studies. The tendency has been to focus on global convergence or convergence with the US GAAP, IFRS or global regulations.

The international nature of financial reporting standards is not determined by the global team of people who develop the standards, but rather by the nature and scope of the standards ( Kamela-Sowinska, 2013).

The crisis of the accounting paradigm is dying out, accounting will cease to be a standard science (compare Kuhn 2009). The complexity of accounting is outpacing its precision, and once eliminated, the departures from rules reoccur in a different place. Today, an account is the first resort in any discrepancy. The external factors seem to contradict faithful representation and years of tradition. What we need is a new theory of accounting to address the present economic crisis, and determine the role of accounting in the crisis. What we used to see as a result before, now we must learn how to perceive as a cause. Financial result used to be seen as the result of undertaken actions, but today it is considered the cause of these actions. As regards the integration of accounting in the EU, I can see clear lack of theoretical premises to effect the proposed changes. Only consistent application of accounting theories in the integration process could ensure linguistic precision, clarity, argumentative order, and correlation between the specialist language and both practice and social awareness.

\section{Dilemma Over Legal Regulations and the Legitimization of Standard Setters}

Another dilemma over the integration of accounting could, in my view, be attributed to accounting regulations as legal norms. A classic example of this might be the transition from rule-based to principle-based IFRSs. In literature, it is common for accounting rules to be juxtaposed with accounting principles. However, it is unjust to distinguish between the two. Principles and rules (or legal principles and norms according to the Polish science of law) differ as to the mode they function. Rules (norms) are based on the 'all or nothing' concept, i.e. they are or aren't met. On the other hand, 
standards (principles) may be observed to a certain extent. Compared to rules, in case of two conflicting standards, principles do not overrule one of them, but are used to give priority to one over the other, with both remaining in force. The application of norms is precisely determined, which is not the case for principles. In addition, rules are applied automatically in particular situation, e.g. double entry rule, whereas the use of principles is conditional upon the entity's assessment of a situation, e.g. the choice of asset measurement method.

One could refer to Dworkin fundamental work Taking Right Seriously, and the famous polemics of John Mackie. Dworkin splits the law into rules and standards, with the latter covering principles and policies. Principles are legal norms to be observed, because they constitute requirements attributed to a certain moral system (justice or honesty). Policies mean standards determining general objectives of social, political, and economic activities. Both types of standards require certain state of affairs to be satisfied to the highest possible extent, with legal and actual functions determining the feasibility of this process. In 2006 critical analysis of confusing rules with principles in drafting accounting standards and standards on auditing was carried out by Benston et al. (2006). However, I couldn't find any reflection of or discussion over, the global heritage of the theory of law or accounting.

The growing acceptance by countries across the globe of International Financial Reporting Standards (IFRS), issued by the International Accounting Standards Board (IASB), is being used by some to suggest that the IASB is a model for a transnational standard-setting body (compere Lloyd et al., 2007; Büthe \& Mattli, 2008, pp. 225-262).

The increasing use of transnational standard-setting bodies to address quality uncertainties and coordination issues in the global economy raises questions about how these bodies establish and maintain their legitimacy and accountability beyond the sovereignty of democratic states. Discussion about legitimacy has increasingly emphasized due process norms in its claim for support. The analysis evaluates the IASB due process against the cultural benchmarks established by domestic standard-setters in the USA and UK and against a normative model of procedural legitimacy. These comparisons help to understand the modifications that were made in the hope due process would add legitimacy to setting accounting standards beyond the state level. They also reflect the broader political context of competing legitimacy criteria faced by transnational standard-setters. (Richardson \& Eberlein, 2010) 
The European Parliament (EP) of the European Union, which accepted the IFRS as the basis for financial reporting by companies starting to operate in 2005, noted in the 2008 motion, adopted by its Committee on Economic and Monetary Affairs, that the IASB:

“... is a private self-regulatory body which has been given the role of lawmaker for the EU... [the EP] underlines that the IASCF/IASB... lack transparency, legitimacy, accountability and are not under control of any democratically elected parliament or government, without the EU institutions having established the accompanying procedures and practices of consultation and democratic decision-making that are usual in its own legislative procedures..." (European Parliament, 2008, p. 4).

This dilemma has its roots in the legal aspect of accounting. Broadly speaking, legitimization means justification or legality of a certain social formation. Most common concepts are: legitimization of power, state, or law.

Legitimization of law means justification of law and perceiving it as fair. Legitimization of law is often intertwined with legitimization of power. Interchangeably with legitimization, such concepts as justification, empowerment or rationale behind the binding force are used. Usually, legitimization is analyzed from normative or empirical perspectives. In normative terms, the concept refers to the justification of certain legal norms. All legal norms, as well as the legal system in its entirety, should have such justification (reference to a certain system or quality) to deserve respect and be regarded as law.

Empirically, legitimization means actual compliance with the law. Therefore, high legitimization of laws demonstrates itself in its provisions being followed by a given society.

Legitimization could be viewed from more or less general perspectives. Thus, we can talk about legitimization of specific legal norms or decisions to set and apply laws, or about legitimization of the entire legal system. The integration of accounting laws should be seen from the second perspective. The IASB does not have the status of an international body such as IFAC, the World Bank, IMF, or the EU. For the proposed standards to obtain legal force, they must be subject to so called due process. The significance of due process has been referred to on IFRS Foundation's website by David Sidwell, Trustee: "we will look at providing more robust documentation to demonstrate the oversight." 
IASB is an institution established in accordance with legal criteria for developing international accounting and audit regulations, hence its activity is rather legal than legitimized.

Without legitimization it wouldn't be possible to exercise power, or establish proper relationships between the authorities and the society. Thus, it is necessary to determine general principles for legitimization, adequate for a given model of governance. In fact, such legitimization remains in the hands of a national legislator.

The discussion over the legitimization of the accounting law requires answering the question: "who controls the processes of accounting integration?" since the participants of this process often present divergent viewpoints, and sometimes even opposite priorities. If we look at IFRS for SMEs, they are not commonly accepted by the accounting profession in the EU, and are still subject to standardization.

Reporting standards for public finance sector should be of particular interest within the EU. The present crisis in Greece, and the imminent crisis in the Southern Europe require focusing on this area of accounting. So what? Well...nothing.

\section{Dilemma over the Politicization of Accountancy}

Over years there was no law on accounting, neither an act nor a code of accounting. There was only practice, which determined how to recognize the results of economic decisions and present them in the measure of value - money. The first modern code containing accounting standards was the Napoleon's Code of 1807 and Commercial Code of 1808 (Code de Commerce); followed by German commercial law BGH Burgerlische Gesatz Buch of 1900. The regulations of the Commercial Code and the Napoleon's Code referred to keeping and using accounting books and preparing a bankruptcy balance sheet. Title II of the Napoleon's Code dealt with merchandise books. For example, in article 10 it obligated merchants to sign the register book and inventory book every year (Turzynski, 2010).

Today we have accounting law, IASs, IFRSs, GAAP, IPSASs. There is a huge number of organizations that formulate rules, principles, conceptual frameworks, accounting standards. The most important of them are: IASB, IFRSB, IFAC, EFRAG, IFRIC, SAC. Most of the international organizations mentioned above all act in the public interest, hence allegedly in the interest of all citizens in the world. Nowadays politicians create accountancy, as they have the power to create the law. This is what is called a politicization of accountancy. The number of publications has risen (Ball, 1995, 
pp. 14-15; Colasse, 2004; Graham \& Neu, 2003, p. 27; Nobes \& Parker, 2012 ).

Literature indicates that the phenomenon is linked to the emergence of critical accounting research, which assumes that accountancy is not a neutral and objective tool aiming at improving the effectiveness of financial markets, but on the contrary - a practice that allows to transfer wealth among social classes. Hence, accountancy influences the authorities in the area of political economics, but at the same time it is influenced by them, as it functions within certain political frameworks. Accountancy has, therefore, a political function - the accounting principles are shaped by the group in power and their ideology and, on the other hand, accountancy influences the way in which profits, wealth and power are being distributed within the society. Literature on political accountancy encompasses works which investigate how accountancy can be engaged in social conflicts and in the process of profit distribution not only within one company, but within the capitalist society as a whole. The research also includes a study on the role of accountancy in the interactions between a country's economic policy and free-market economy (Dobija, 2010).

A Corporate Social Responsibility report, (CSR report) is supposed to present what a particular company decided to do in the following three areas: economic, social and environmental, and whether it has managed to accomplish the goals set. A report on sustainable development is an important source of information for financial analysts who formulate prognoses regarding future financial results of the company. Based on the information included in such reports, their prognoses are more precise and reliable. By preparing a CSR report, the company contributes to building better social and environmental conditions, and consequently - it may trigger positive changes in the global economy. Moreover, emphasizing its openness and transparency, the company improves its relations with local community, non-profit organizations etc.

A CSR report can also play a role of a marketing tool, which creates an image of a company devoted to social and environmental issues. It can help the company to gain advantage over its competitors, who are less concerned with the idea of sustainable development. By promoting activities in the area of sustainable development, companies promote transparency and responsibility over their actions and results.

The more globalized and complex the economic environment is, the more of political intervention there is expected to occur in the standard setting process. Regardless of whether the standard-setting institutions represent the public or private sectors, accounting principles will be shaped by 
the global geopolitical reality, so by following this tendency, accountancy is obtaining geopolitical knowledge and practice in EU countries.

\section{Conclusions}

The developments of international accounting bodies and standard setters have played a vital role in ensuring best accounting and audit practices will be disseminated across the complex modern world. On the other hand, it heralds a number of problems that will have to be solved in near future.

The main role of implementing new solutions in accountancy and audit may be played by IFAC which, in a document "Enhancing organizational reporting" stated that IFAC:

- Supports organizational reporting of broad-based information that is important to stakeholders for managing and directing operations, decision making, promoting transparency, and the discharge of accountability;

- Supports such reporting in accordance with robust international reporting frameworks that produce information on which assurance conclusions can be expressed, in accordance with high-quality international assurance standards;

- Recognizes that the accountancy profession has a significant contribution to make, and an important role to play, in developing and implementing enhanced organizational reporting.

Professional accountants also play an important role in broad-based organizational reporting arrangements, and in providing assurance:

- Strongly supports the International Integrated Reporting Council (IIRC) and the development of the Integrated Reporting $(<I R\rangle)$ Framework;

- Recognizes that there is a range of different frameworks and regulations available and being developed, and considers it important to examine the relationship between these frameworks and to promote global consistency and convergence (www.IFAC.org, IFAC Policy Position 8,October 2013).

Key focus areas of discussion related to the integration of accounting in the EU are as follows:

- whether to strengthen the role of the Word Bank, IMF, EU, and IFAC in developing accounting standards for the public finance sector and focus the standardization of business accounting exclusively on listed entities; / is it reasonable to strengthen ....

- whether to strengthen the role of Directives and Conceptual Frame- 
works as the basis for regular accounting to clearly define practical rules and principles; / is it reasonable to strengthen ....

- whether to strengthen the role of national standard setters based on Directives and Conceptual Frameworks, particularly as regards SMEs, since it's only them who can acknowledge the cultural and other specific features of their domestic system. / is it reasonable to strengthen.

\section{References}

Bagshow, K. (2006). Principles v. Rules. Accountancy Magazine, December Ball, R., (1995). Making Accounting more International. Journal of Applied Corporate Finance, 8(3).

Ball, R. (2006). International Financial Reporting Standards (IFRS): pros and cons for investors. Accounting and Business Research, 15, http://dx.doi.org/10.1 080/00014788.2006.9730040.

Benston, G. J., Bromwich, M. \& Wagenhofer, A. (2006). Principles- Versus RulesBased Accounting Standards, The FASB's Standard Setting Strategy. Abacus, 42(2), http://dx.doi.org/10.1111/j.1467-6281.2006.00196.x.

Berle, A. A. \& Means, G. C. (1932), The Modern Corporation and Private Property. Transaction Publishers.

Biernat, T. (2007). Legitymizacja władzy politycznej. Elementy teorii. Torun: Wydawnictwo Adam Marszałek.

Colasse, B. (2004). The International Standardization of Accounting; the Resistible Rise of the IASC/IASB Gerer et Comprendre, 100(2), http://dx.doi.org/10.391 $7 /$ geco.100.0015.

Directive 2013/34/EU of the European Parliament and of the Council of 26 June 2013 on the annual financial statements, consolidated financial statements and related reports of certain types of undertakings, amending Directive 2006/43/EC of the European Parliament and of the Council and repealing Council Directives 78/660/EEC and 83/349/EEC.

Dobija, D. (2010). Dylematy standaryzacji sprawozdawczości finansowej, wyceny i pomiaru zysku, Zeszyty Naukowe, SKwP, 57(113).

Dworkin, R. (1998). Biorac prawa poważnie. Warszawa: Wydawnictwo Naukowe PWN.

European Parliament (2008). Report on International Financial Reporting Standards (IFRS) and the Governance of the International Accounting Standards Board (IASB), Committee on Economic and Monetary Affairs, Rapporteur: Alexander Radwan [A 6-0032/2008, 2006/2248(INI)], 5 Feb. 2008.

Graham, C., \& Neu, D, (2003). Accounting for Globalization. Accounting Forum, 27(4), http://dx.doi.org/10.1046/j.1467-6303.2003.t01-1-00114.x.

Higson, A. (2003). Corporate Financial Reporting, theory and Practice. Sage Publication LTD.

IFAC Policy Position 8,October 2013. www.IFAC.org 
Kamela-Sowinska, A. (2011). Geopolityka rachunkowości. Prace i Materiały Wydziału Zarządzania Uniwersytet Gdański, 1(1).

Kamela-Sowinska, A., (2013). Rachunkowości dylematy integracji rachunkowości w krajach Unii Europejskiej. Studia Oeconomica Posnaniensis, 1(8).

Kothari, S. P. (2012). The Role of Accounting in the Financial Crisis: Lessons for the Future. Accounting Horizons, 20(2), http://dx.doi.org/10.2308/acch-50134.

Kwiecień, R., (2010). Teoria i filozofia prawa międzynarodowego. Problemy wybrane. Warszawa: Difin.

Kuhn, T. S., (2009). Struktura rewolucji naukowych, Warszawa: Wydawnictwo Eletheia.

Lloyd, R., Oatham, J., \& Hammer, M., (2007). Global Accountability Report, London: One World Trust.

Mackie, J. (1984). The Third Theory of Law. In R. Dworkin. Contemporary Jurisprudence. Duckworth Edition.

Mattli, W. \& Büthe, T. (2005). Global Private Governance: Lessons from a National Model of Setting Standards in Accounting . Law and Contemporary Problem, 68(3/4).

Nobes, Ch. \& Parker, R. H. (2012). Comparative International Accounting. UK: Amazon.

Richardson, A., J. \& Eberlein B. (2010). Legitimating Transnational StandardSetting: The Case of the International Accounting Standards Board. Journal of Business Ethics, 98(2), http://dx.doi.org/10.1007/s10551-010-0543-9.

Ryan, S., (2008). Accounting in and for the Subprime Crisis. Accounting Review, $83(6)$.

Quinton, M. (2002). Principles Versus Rules in Financial Supervision, International Monetary Fund, March 2002,WP/02/46.

Watts, R., \& Zimmerman, J. (1986). Positive Accounting Theory, Englewood Cliffs, NJ: Prentice-Hall. 